\title{
Fungi Associated With Post-harvest Avocado Fruit Rot at Jimma Town, Southwestern Ethiopia
}

\author{
Minyahil Kebede ${ }^{1,2 *}$ and Addisie Belay ${ }^{2}$ \\ ${ }^{1}$ Ethiopian Institute of Agricultural Research, Assosa Agricultural Research Centre, Asosa, Ethiopia; ${ }^{2}$ Department of Horticulture and Plant \\ Science, Jimma University College of Agriculture and Veterinary Medicine, Jimma, Ethiopia.
}

\begin{abstract}
The poor post-harvest handling of avocado in and around Jimma was contribute its part for Post-harvest decay of avocado fruits and loss in quality of avocado. Besides, Post-harvest disease can limit the storage period for the fruit. The aim of this study was to identify Post-harvest pathogens affecting avocado fruits in Jimma town. A total of 35 avocado fruits categorized as apparently healthy (20), diseased (10) and decayed (5) avocado fruits were sampled from wholesalers, local market and farmers' field during 2017. A total of 30 fungal isolates were recovered and grouped into nine fungal species under eight genera. Botryotinia was the most frequently isolated genus $(26.67 \%)$ followed by Colletotrichum (23.33\%) and Aspergillus (10\%). Thus, requests the need of management strategy that targets in reducing factors that facilitates the occurrence of fungal infection such options are avoidance of avocado fruit damaging practices by using locally available cushioning materials during loading to cars, avoiding loading of people and other materials together with avocado fruits on the same car, improving avocado storage houses to allow air circulation and avoiding damping of avocado fruits in the storage house.
\end{abstract}

Keywords: Breeding; Post-harvest fungal pathogens; Quiescent infection

\section{INTRODUCTION}

Avocado (Persea americana Mill.) belonging to the family Lauraceae, is one of the most economically important tree fruit crops in the world and is native to Mexico and Central America [1,2]. It was introduced to Ethiopia (particularly to Wondogent and Hirna areas) by private orchardists in 1938 and then from these areas, it was progressively spread to different parts of the country where the crop was adapted including South-western Ethiopia [3-5]. Currently, the crop is cultivated worldwide in tropical and subtropical areas for its high nutritional and calorific value such as vitamins (B5, B6, B9 and E), minerals (higher potassium content), a great amount of oil (used to produce cooking oil, cosmetics and some soaps) and used in different dishes. Besides, its high monounsaturated fat content makes it a good substitute for vegetarians or people without access to meat and dairy products $[2,6,7]$.

In Ethiopia, due attention was given by the government to expand avocado production and productivity for export, domestic consumption and industrial processing [8], but still its production is infant in the country due to several constraining factors including disease problems, lack of rigorous public support, insufficient information system, degeneration of fruits, poor transportation, high handling costs and absence of agronomic practices $[6,9,10]$ Additionally, there is no value additions of avocado along supply chain from farmer, broker, or wholesaler levels and also fruits are sold unprocessed [11].

Microbial pathogens (diseases) are the ones that mainly caused substantial losses of fruits both at preharvest and Post-harvest stages of production. Pathogen infection may occur during growing period, harvesting, handling, shipping, storing, marketing and/or after procuring by the consumer [12,13]. Among the pathogens, fungi are the number one pathogen responsible for severe Postharvest losses of perishable fruits, vegetables and other horticultural crops due to their high moisture, high sugars (in fruits) and low $\mathrm{pH}$ that provokes fungal growth leading to fruit deterioration and decay. All these reduce the quality and sometimes cause completely unmarketable produces that fall in meeting the standards for exports. Because of this, producers and traders sold their produce in less demanding local markets at lower prices; resulting in an economic loss [14-18]. Besides, fungal pathogens can attribute to quality loss and health hazards through the production of toxins.

In lower income Sub-Saharan African countries, occurrences of Post-harvest losses (from farm to fork) are the main problems that

Correspondence to: Minyahil Kebede, Ethiopian Institute of Agricultural Research, Asosa Agricultural Research Centre, P.O. Box-625, Assosa, Ethiopia, Telephone: (+251) 577-752451; E-mail: minishkebe@gmail.com

Received: January 01, 2019; Accepted: March 18, 2019; Published: March 25, 2019

Citation: Kebede M, Belay A (2019) Fungi Associated With Post-harvest Avocado Fruit Rot at Jimma Town, Southwestern Ethiopia. Plant Pathol Microbiol. 10:476. doi: 10.35248/2157-7471.10.476

Copyright: (C) 2019 Kebede M, et al. This is an open-access article distributed under the terms of the Creative Commons Attribution License, which permits unrestricted use, distribution, and reproduction in any medium, provided the original author and source are credited. 
exacerbates food insecurity [19]. Even in developed countries, microbial pathogens caused nearly 20-25 percent deterioration of the harvested fruits during Post-harvest handling [20]. With this, this study was aimed to examine, identify and provide information on Post-harvest fungal pathogens of avocado responsible for Postharvest deterioration and decay of avocado fruits in Jimma town.

\section{MATERIALS AND METHODS}

\section{Description of the study area}

The study was conducted during 2017 in Jimma town which is the administrative city of Jimma zone of Oromia region, Ethiopia. The town is located at 352 kilometres far away from Addis Ababa to the southwestern direction. Geographically it is situated at latitude of $7.667^{\circ} \mathrm{N}$ and longitude of $36.83^{\circ} \mathrm{E}$ having an elevation of 1763 m.a.s.l.

\section{Sample collection}

Ten apparently healthy avocado fruits from two farmers (five from each) were randomly sampled from freshly harvested avocado fruits to examine fungal quiescent infection. Also, tow avocado wholesalers were selected at random in Jimma town and then a total of 20 avocado fruits were sampled. One of the wholesalers has fairly ventilated store, while the other had poor storage system. From the fairly ventilated store five apparently healthy avocado fruits were randomly sampled. Whereas, from the poorly stored avocado 15 avocado fruits were sampled as followed; five diseased, five apparently healthy and five already exhibited mould growth (Figure 1). Additional five avocado fruits were randomly sampled from a local market known as 'Bishishe' in Jimma town. Finally, all the sampled (a total of 35) avocado fruits were taken to plant pathology laboratory of Jimma University College of Agriculture and Veterinary Medicine for isolation and identification of fungal pathogens associated with Post-harvest avocado fruits in Jimma, Ethiopia (Figures 1-5).

\section{Assessment of quiescent infection}

All the apparently healthy samples collected both from wholesalers and farmers were kept at room temperature in clean and disinfected plastic boxes. Inspection of the fruits was started after five days and thereafter every five days in order to estimate the percentage disease incidence (diseased/decayed fruits); which was determined as follows:

$$
\begin{aligned}
& \text { Incidence }(\%)=\frac{\text { Number of disease / decayed fruits }}{\text { Total number of sampled fruits }} \times 100 \\
& \text { Isolation procedures }
\end{aligned}
$$

\section{Isolation procedures}

From all collected samples four small pieces were cut off and surface sterilized by 3 percent (v/v) Sodium hypochlorite for one minute then after rinsed three times with distilled water. The sterilized pieces then allowed draining under fume hood. The drained pieces were placed on PDA media and incubated at $25^{\circ} \mathrm{C}$ for 3 to 7 days. After that, fungal isolates were purified on PDA depending on their colony colour.

\section{Morphological identification}

The morphological identification of the fungal isolates were done based on mycelial colony and microscopic features by using the identification manuals namely A pictorial guide for the identification of mould fungi on sorghum grain [21]; Identification Key for Aspergillus species Isolated from Maize and Soil of Nandi County, Kenya [22]; Morphological and molecular characterization of Colletotrichum gloeosporioides (Penz) Sac. isolates causing anthracnose of orchids in India [23] and The Pictorial Atlas of Soil $\&$ Seed Fungi Second Edition [24].

\section{RESULTS}

\section{Assessment of avocado storage facilities}

The source of avocado fruits supply to Jimma town was districts in Jimma zone of Oromia region and nearby districts namely Koya and Amaya districts (during offseason) of Southern Nations
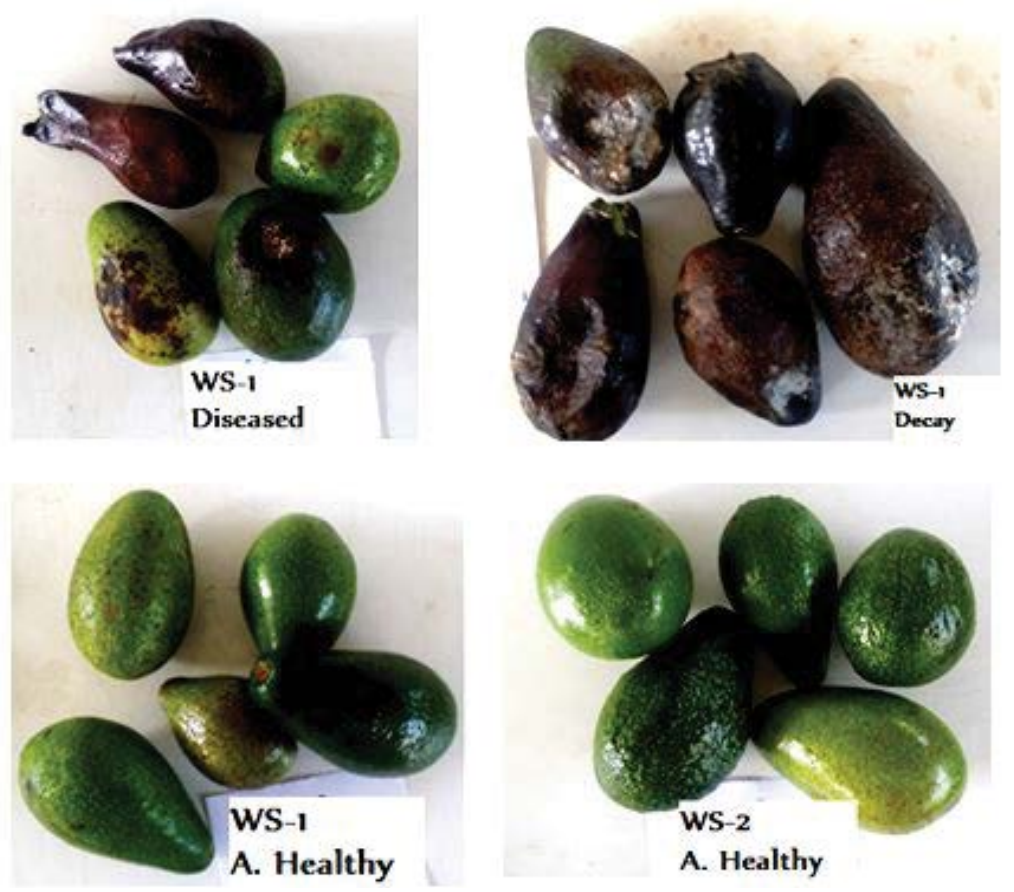

Figure 1: Samples of avocado fruit collected from wholesalers. (WS-1=Wholesaler-1; WS-2=Wholesaler -2; A. healthy=Apparently healthy). 
Nationalities and People region (SNNPR) of Ethiopia. The middleman bought physiologically mature avocado fruits from producers at farm gates and transported it with the help of 'ISUZU' truck to storage houses (wholesalers) in Jimma town. Often, during loading into ISUZU truck they don't used cushioning materials or they doesn't practiced any means that can reduce fruit damages (Figure 2). Besides, people were loaded on top of avocado fruits that can cause damage to avocadoes.

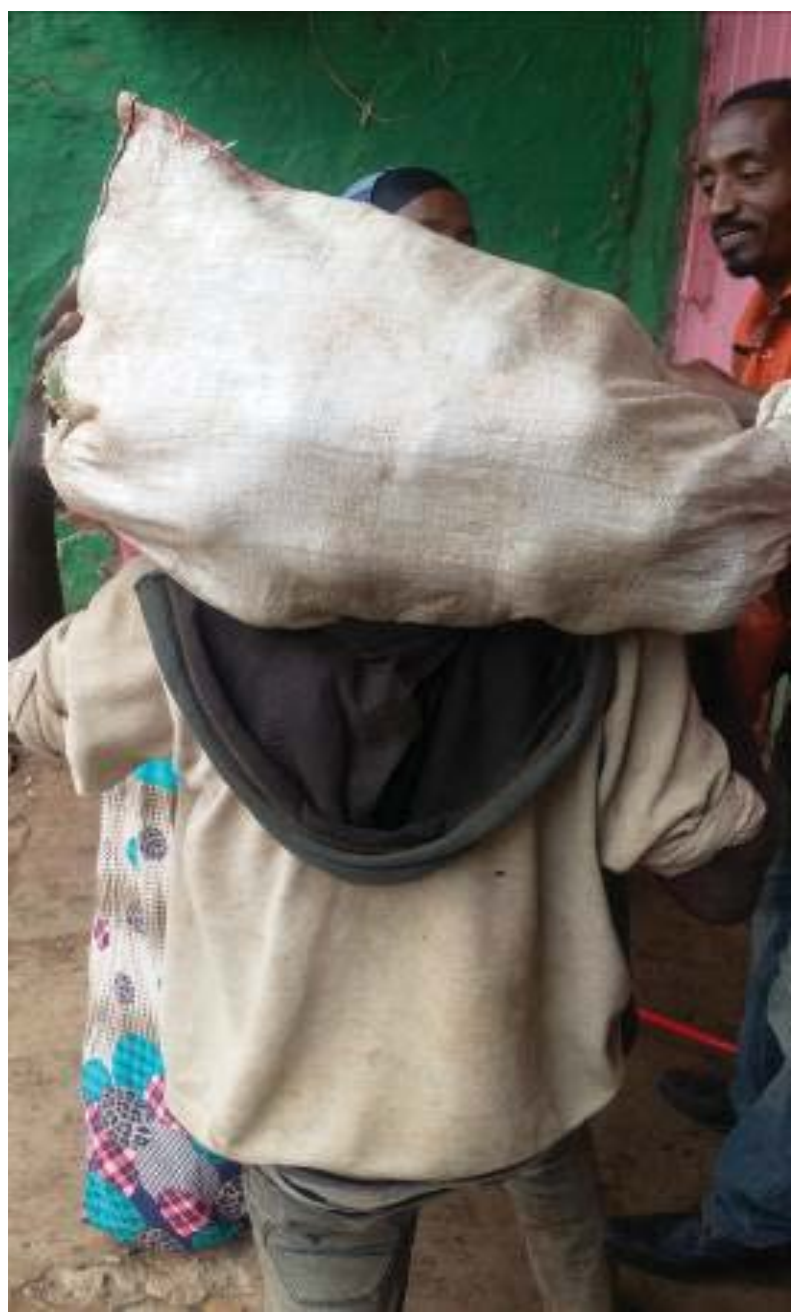

Figure 2: During loading to cars.
On top of these, the storage houses were not well ventilated particularly in the case of wholesaler-I (Figures 3-5), due to this the fungal pathogens were favoured and thus caused severe deterioration and decay (Figure 3). For instance, the owner of wholesaler-I told that almost one-fourth of the stored avocados were avoided due to deterioration and decay through continuous inspection and collection of decayed avocado fruits for disposal (Figure 3). In wholesaler-I, the avocados were damped and also there was lack of ventilation that provokes the fungal development and resulted in $40 \%$ of avocado fruits showed moldy fungal growth that probably cause avocado decay (Figure 3). On the other hand, wholesaler-II has somewhat good ventilated storage house in the top wells (Figures 4 and 5), that saved their avocado from deterioration or decaying problem. But, their storage facility was yet a traditional type.

Due to the quiescent infection of fungal pathogen, $60 \%$ incidences of decayed avocado fruits were recorded on apparently health samples collected from wholesaler-I after 10 days storage at room day's temperature. Apparently health samples collected from local market were also showed 40 present incidences of decayed avocado fruits whereas, those apparently healthy avocado samples collected from wholesaler-II, field-I and field-II does not show any fruit decay under similar situations (Table 1).

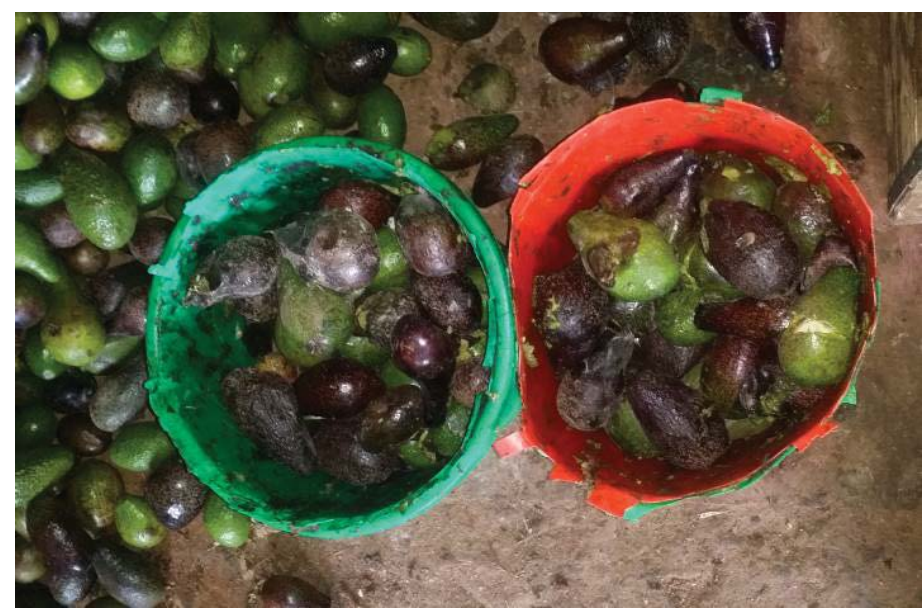

Figure 3: Culling off decayed avocado fruits of wholesaler-I.

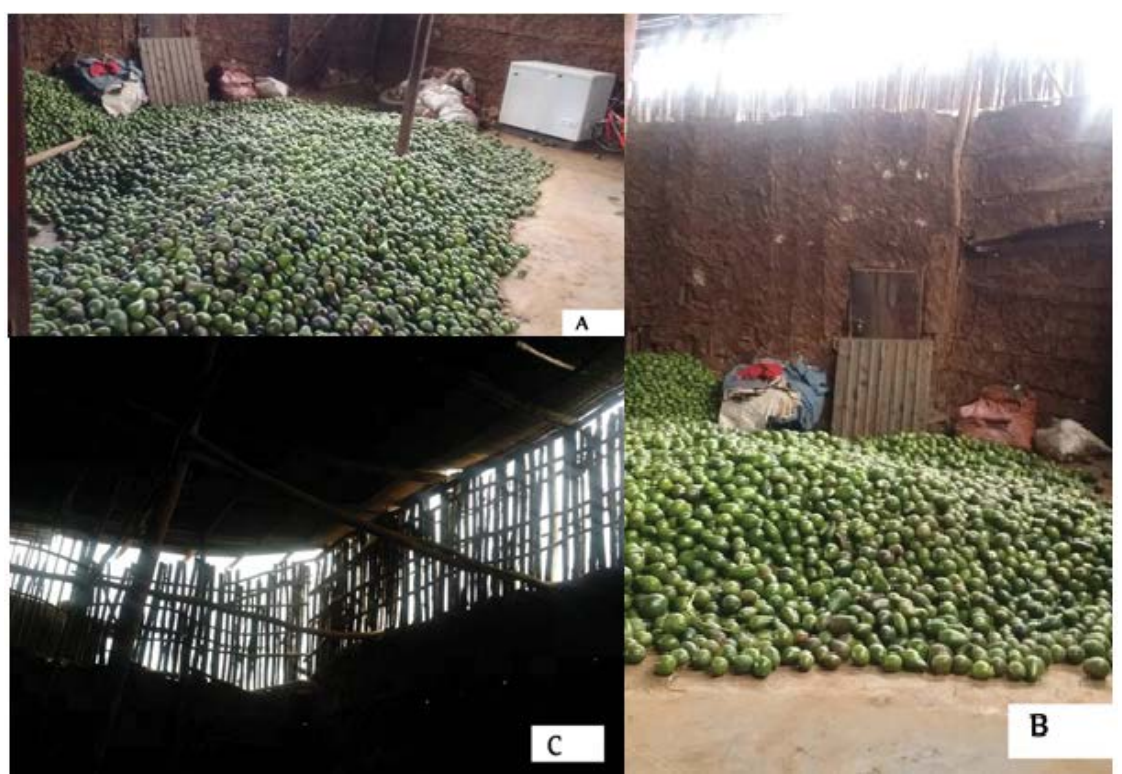

Figure 4: Storage house of wholesaler-II. A=Traditional avocado storage house with good ventilation; B and C= Shows ventilation parts of the storage. 


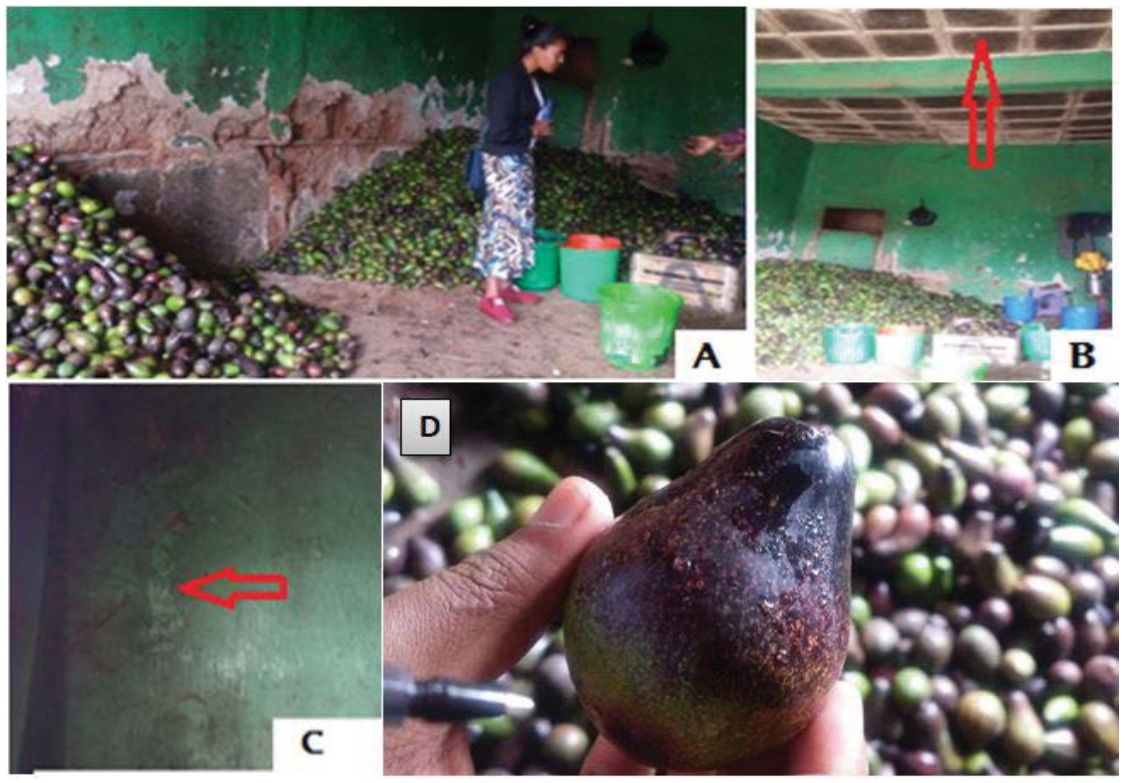

Figure 5: Storage house of wholesaler-I; A=Dumped avocado fruits in unventilated house; B=Moisture on roof sill due to lack of ventilation; C=Evaporated moisture on the well; and $\mathrm{D}=$ Due formed on avocado fruit due to high temperature.
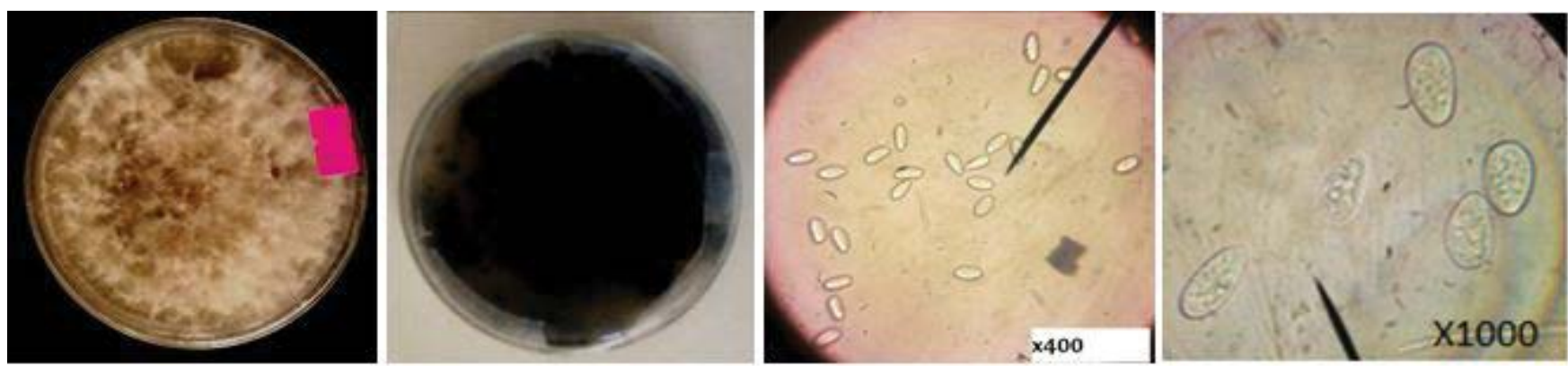

Figure 6: Botrytis spp. on PDA.

\begin{tabular}{|c|c|c|}
\hline S/N & Sample sources & $\begin{array}{c}\text { After } 10 \text { days storage at room } \\
\text { temperature }\end{array}$ \\
\hline 1 & Market & 40 \\
\hline 2 & Wholesaler-I & 60 \\
\hline 3 & Wholesaler-II & 0 \\
\hline 4 & Field-I & 0 \\
\hline 5 & Field-II & 0 \\
\hline
\end{tabular}

Table 1: Percentage incidence of decayed avocado fruits due to quiescence infection.

\section{Identification of post-harvest fungal pathogens of avocado}

In this study, from 35 samples of avocado fruits [grouped as apparently healthy (20), diseased (10) and decayed/moldy (5) collected from farmer fields, market, and wholesalers] 30 fungal isolates were founded. These 30 isolates were identified based on their mycelial colony and microscopic features into nine fungal species belonging to seven genera (Table 2).

Botryotinia was the most frequently isolated genus (26.67 percent) affecting avocado fruits in Jimma followed by the genus Colletotrichum and the Aspergillus having isolation frequency of 23.33 percent and 10 percent respectively. Fusarium and Pestalotiopsis genera were 6.67 percent frequency of isolation, whereas Cladosporium, Mucoraceae, and Candida were the least frequent (3.33 percent) genera isolated from the avocado fruits of the Jimma town (Table 2).

\begin{tabular}{|c|c|c|c|}
\hline S/N & Genus & Species & Frequency of isolation (\%) $\mathbf{n = 3 0}$ \\
\hline 1 & Colletotrichum & $\begin{array}{c}\text { Colletotrichum } \\
\text { gloeosporioides }\end{array}$ & 23.33 \\
\hline 2 & Fusarium & Fusarium spp. & 6.67 \\
\hline 3 & Botryotinia & Botrytis spp. & 26.67 \\
\hline 4 & Cladosporium & Cladosporium spp. & 3.33 \\
\hline 5 & Pestalotiopsis & Pestalotiopsis spp. & 6.67 \\
\hline 6 & Aspergillus & Aspergillus nigir & 6.67 \\
\hline 7 & Aspergillus & Aspergillus flavus & 3.33 \\
\hline 8 & Candida & Candida spp. & 3.33 \\
\hline 9 & Mucoraceae & Rhizopus nigricans & 3.33 \\
\hline
\end{tabular}

Table 2: Frequency of postharvest fungal species of avocado.

\section{DISCUSSION}

This study investigated that Botrytis spp. (Figure 6) and Colletotrichum gloeosporioides (Figure 7) were the most frequently isolated fungal species that had 26.67 and 23.33 percent isolation frequency respectively, whereas Cladosporium spp. (Figure 8), Rhizopus nigricans (Figure 9), Candida spp. (Figure 10), and Aspergillus flavus (Figure 11) were the least isolated species. Moreover, Fusarium spp. (Figure 12), Pestalotiopsis spp. (Figure 13), and Aspergillus niger (Figure 14) were isolated at a frequency of 6.67 percent from avocado fruits of Jimma town (Table 2).

Botrytis spp. were isolated from two avocado sources used in this investigation; namely farmer field-I and wholesaler-I at an 

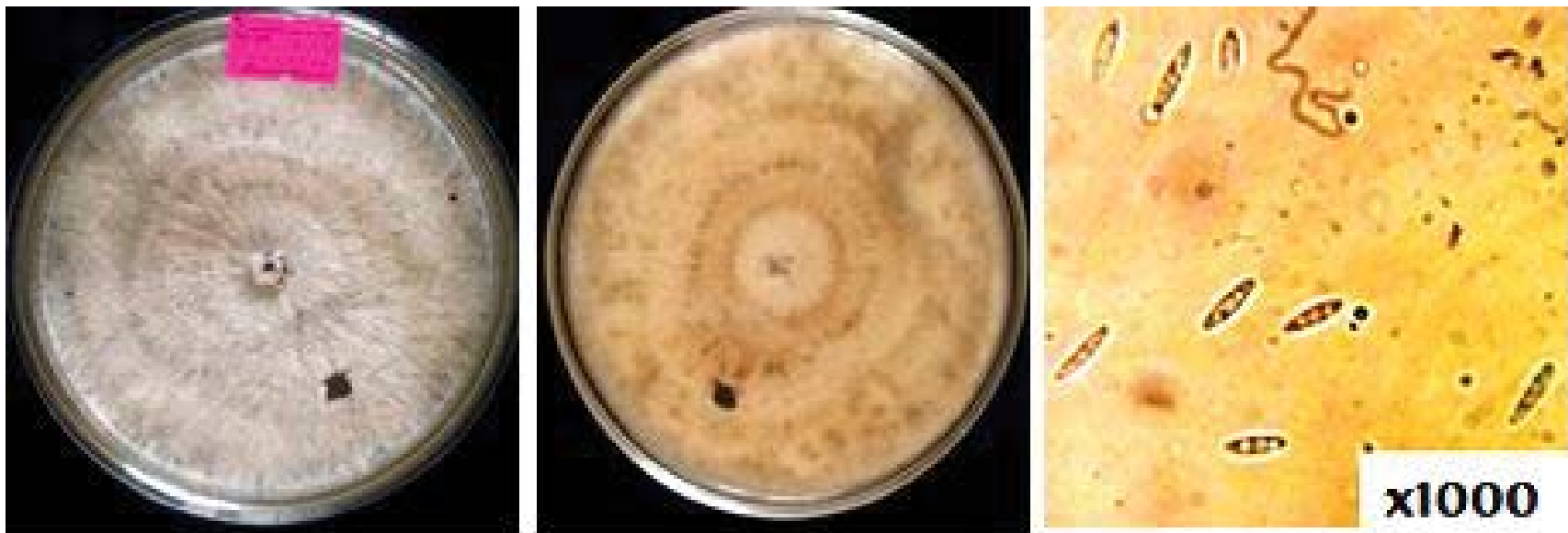

Figure 7: Colletotrichum gloeosporioides on PDA.
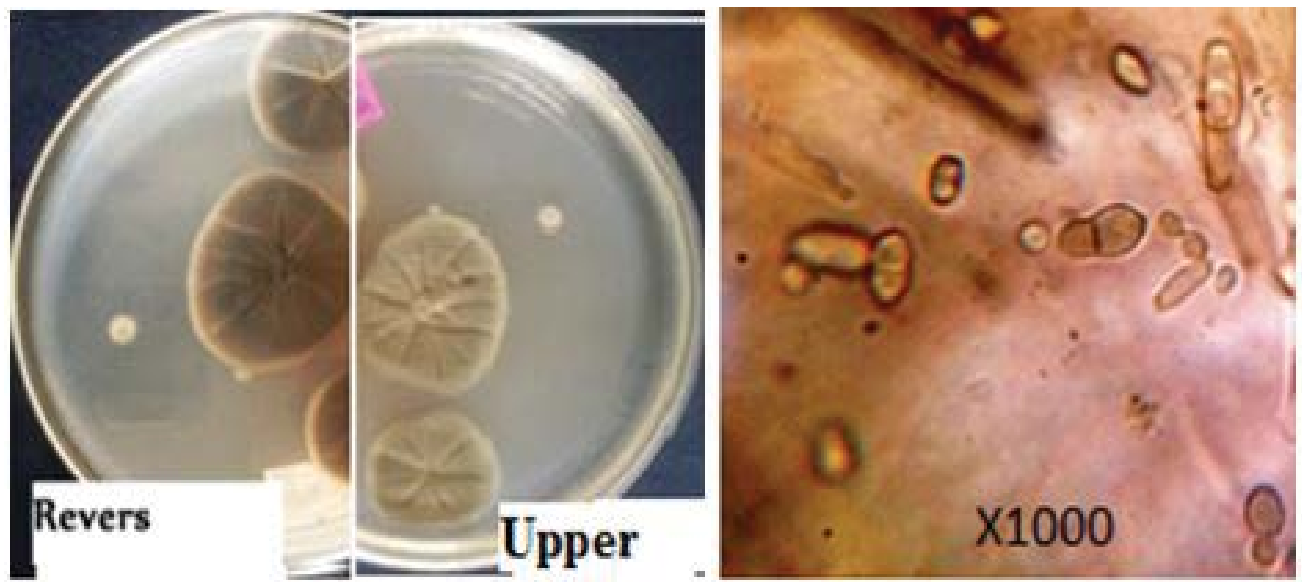

Figure 8: Cladosporium spp. on PDA.
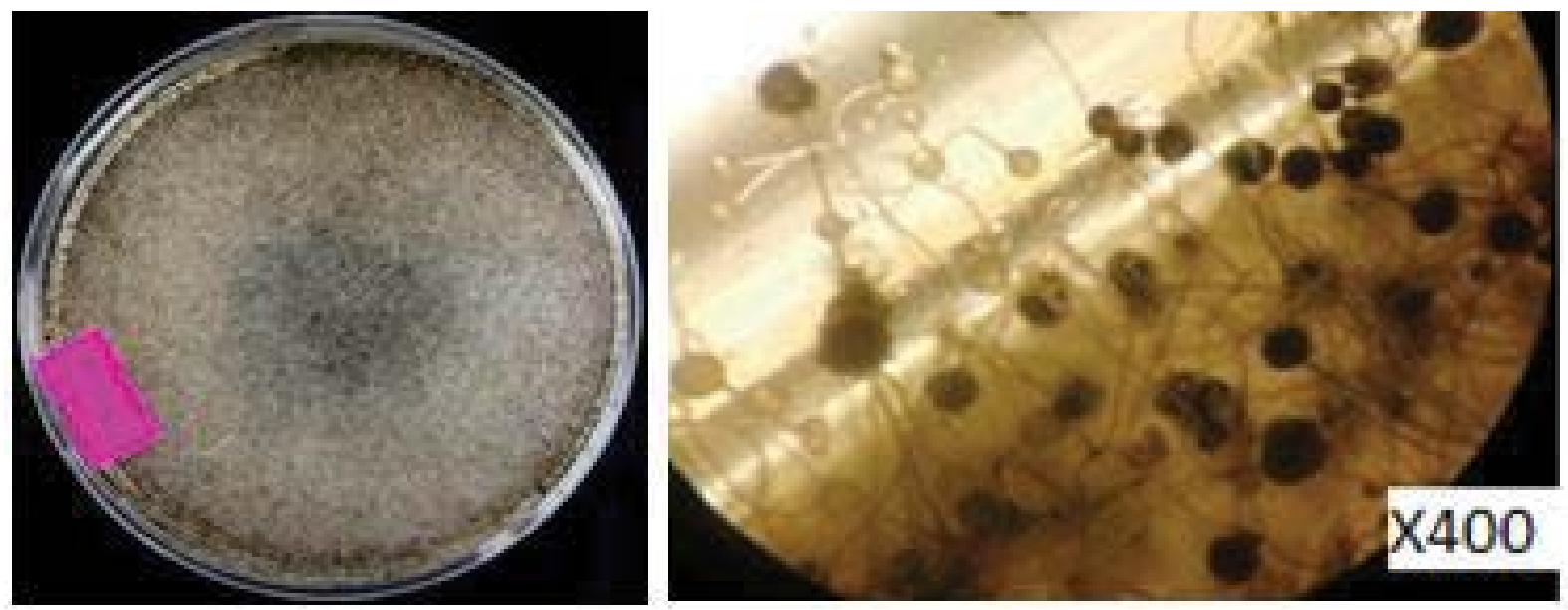

Figure 9: Rhizopus nigricans.
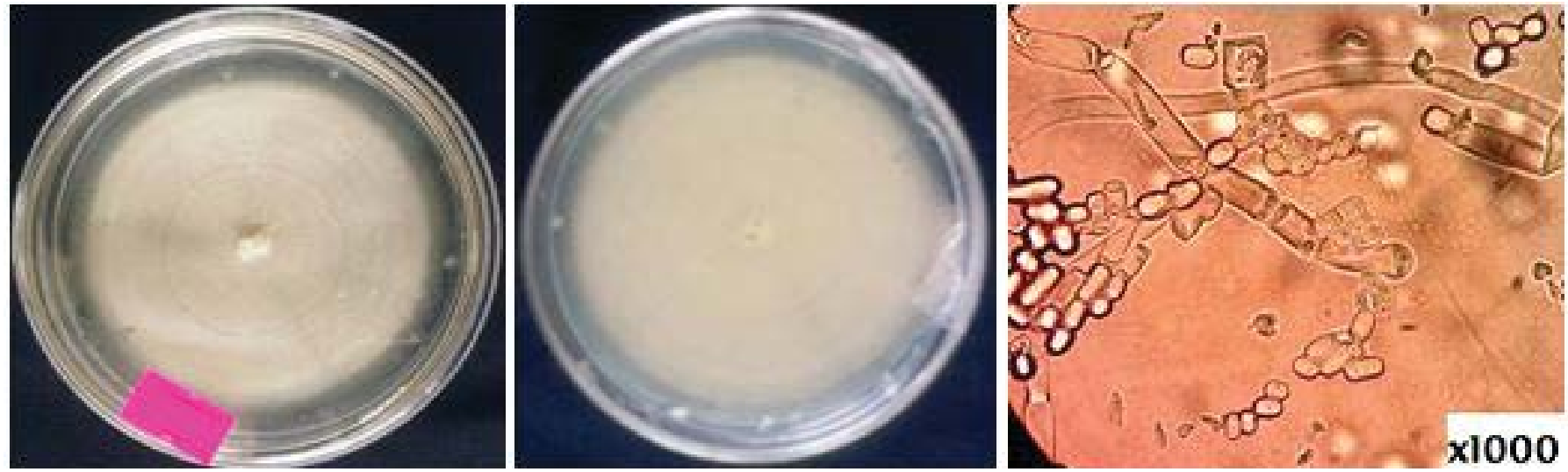

Figure 10: Candida spp. on PDA. 

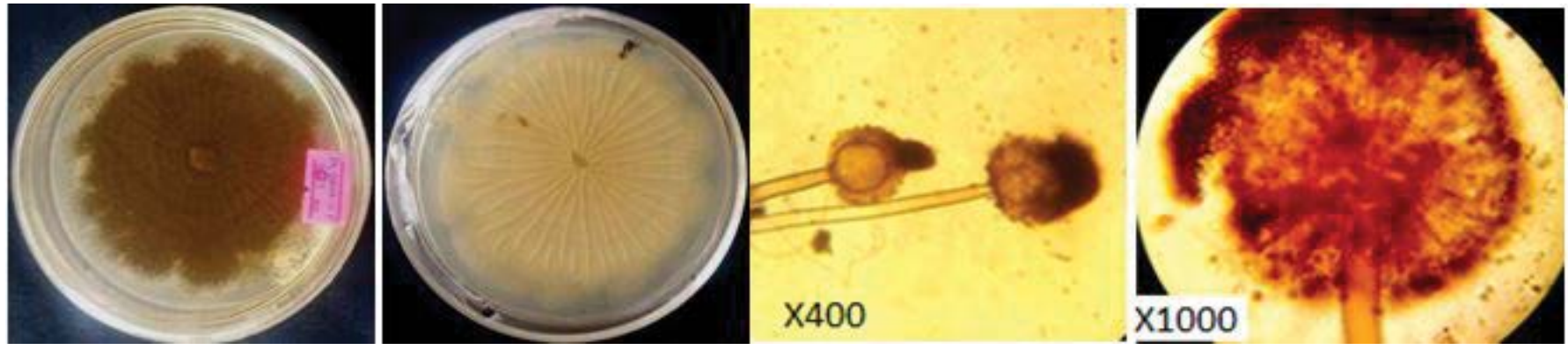

Figure 11: Aspergillus flavus on PDA

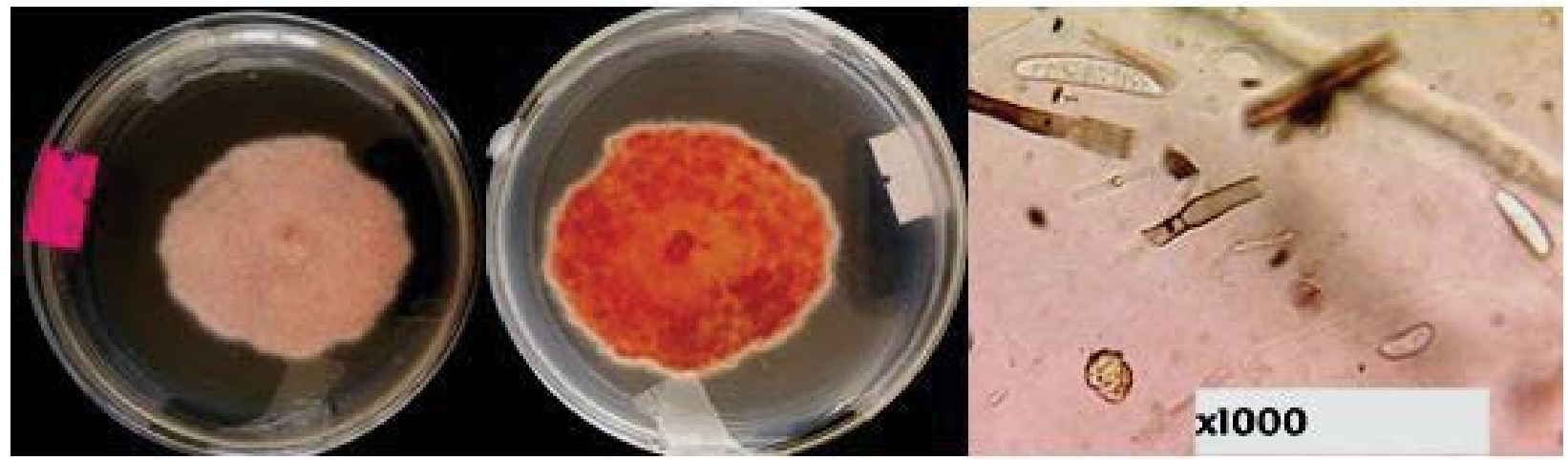

Figure 12: Fusarium spp. on PDA.
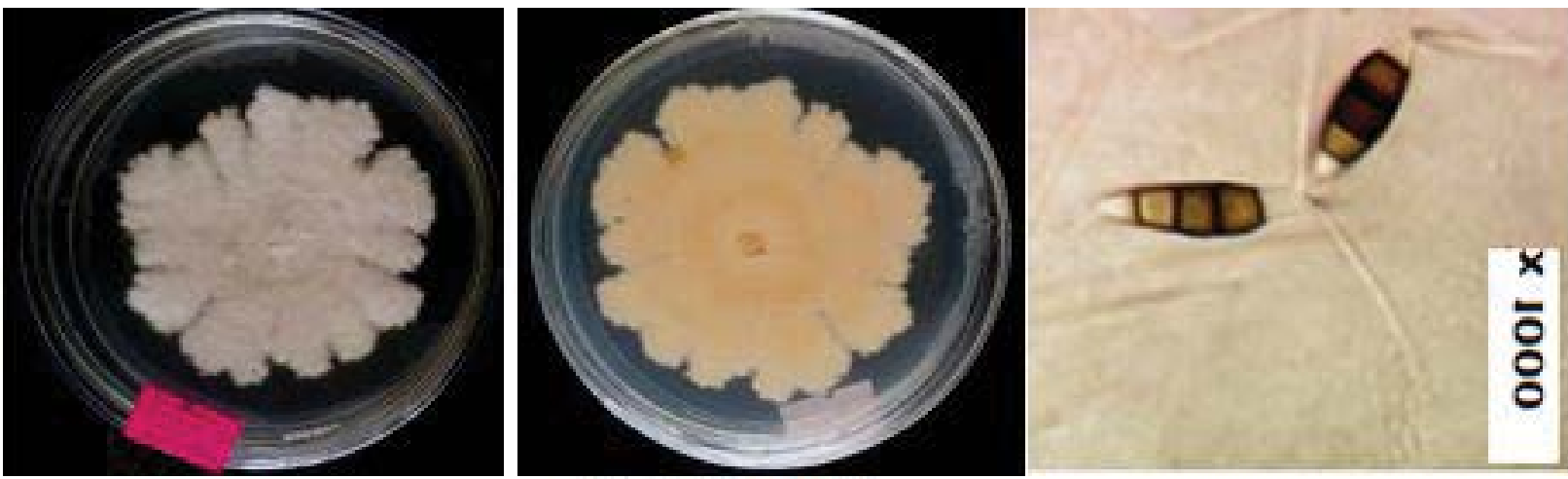

P. clavispora
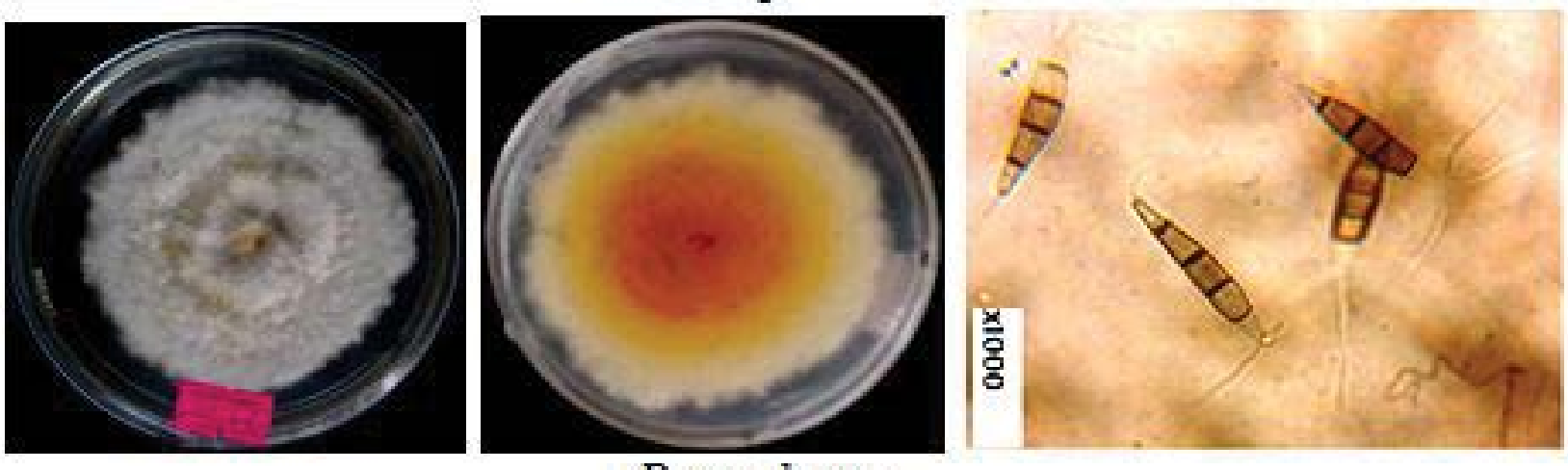

\section{P. neglecta}

Figure 13: Pestalotiopsis spp. on PDA.

isolation frequency of 6.67 and 20 percent, respectively (Table 3). This showed that Botrytis spp. was the major Post-harvest fungal pathogen of avocado fruits in the storage house of wholesaler-I. Thus, it was supposed that the Botrytis spp. attributed their parts for the high deterioration and decay of fruits occurred in the storage as the owner of the store said earlier. On the other hand, in case of wholesaler-II, there was no problem of Botrytis spp., hence their storage house was fairly ventilated. 

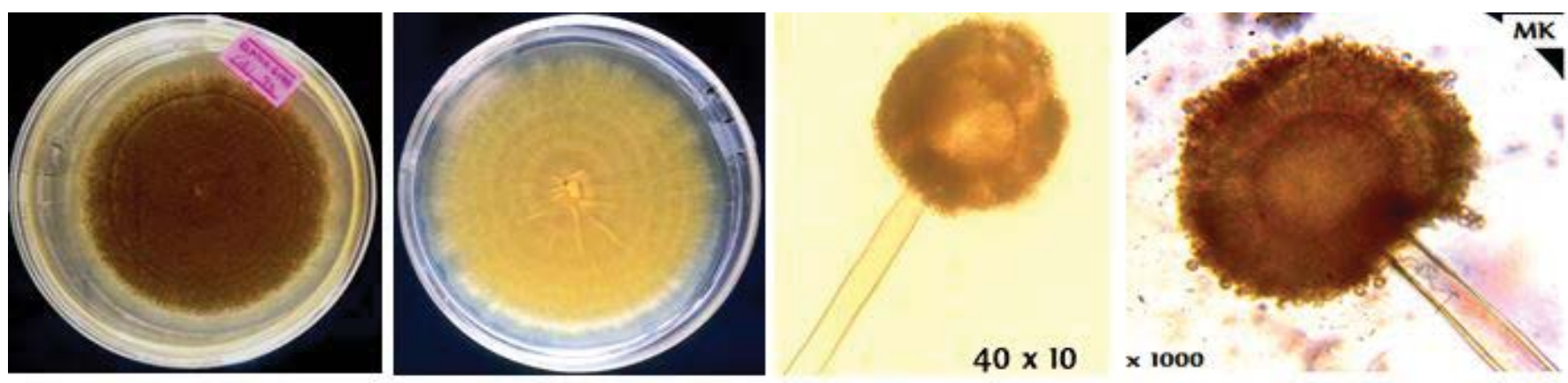

Figure 14: Aspergillus niger on PDA.

\begin{tabular}{|c|c|c|c|c|c|c|}
\hline S/N & Species & Field-I & Field-II & Market & WS-I & $\begin{array}{c}\text { WS- } \\
\text { II }\end{array}$ \\
\hline 1 & Colletotrichum gloeosporioides & - & 3.33 & 13.79 & 6.67 & - \\
\hline 2 & Fusarium spp. & - & - & - & 3.33 & 3.33 \\
\hline 3 & Botrytis spp. & 6.67 & - & - & 20 & - \\
\hline 4 & Cladosporium spp. & 3.33 & - & - & - & - \\
\hline 5 & Pestalotiopsis spp. & - & 3.33 & 3.33 & - & - \\
\hline 6 & Aspergillus nigir & - & 3.33 & 3.33 & - & - \\
\hline 7 & Aspergillus flavus & - & - & 3.33 & - & - \\
\hline 8 & Candida spp. & - & - & 3.33 & - & - \\
\hline 9 & Rhizopus nigricans & - & - & - & 3.33 & - \\
\hline
\end{tabular}

avoiding overcrowding avocado fruits in the storage houses for avoiding dampness and temperature rise in the room.

\section{ACKNOWLEDGEMENT}

Our sincere thanks go to Horticulture and Plant Science Department of Jimma University for allowing us to use the plant pathology laboratory facilities for successful execution of this work.

\section{REFERENCES}

1. Bost J, Smith N, Crane J. History, distribution and uses. The avocado: Botany, production and uses. CABI Publ., Wallingford, UK 2013;10-30.

2. Schaffer BA, Wolstenholme BN, Whiley AW. The avocado: Botany, production and uses, CABI 2013.

3. Edossa E. Selection of avocado (Persea americana.) collection of desirable fruit characteristics and yield at Jimma. Proceedings of the 8th Annual Conference of the Crop Science Society of Ethiopia, Addis Ababa, Ethiopia, Education Ltd, London, UK 1997;26-35.

C. gloeosporioides was the second most important fungal pathogen isolated from avocado fruits collected from farmer field-II, market, and wholesaler-I at frequency of isolation of 3.33, 13.79, and 6.67 percents. Whereas, the rest fungal species had isolated in rarely, but few of them (like A. flavus and Fusarium spp.) are concerned with health hazards, and thus need further clarification works to devices management strategies for them.

In general speaking, this study founded that wholesaler-I (which is less aerated store with dumped fruits) was provided more conducive situation for many fungal pathogens as compared to wholesaler-II. As a result, avoidance of fruit dump in the store and provision of aeration or ventilation can play a role in reducing and/or delaying the occurrence of Post-harvest fungal infection.

\section{CONCLUSION AND RECOMMENDATIONS}

This investigation has provided useful information on postharvest fungi associated with avocado fruits sampled from local market, wholesalers and farmer fields in Jimma town, Southwestern Ethiopia. The results of this study showed that Botrytis spp., C. gloeosporioides, and Aspergillus spp. were the main causal agents of avocado Post-harvest diseases in Jimma. Therefore, there must be a need to devise an appropriate management strategy to manage those important Post-harvest fungal pathogens to reduce their tremendous effect on Post-harvest avocado fruits' quality, deterioration and decay; which in turn reduce an economic loss (low market prices) and health hazards. We also suggest any practices such as the use of locally available cushioning materials that can reduce damage of avocado fruits during loading to cars, careful transportation to storage houses (avoiding people and other materials in loading together with avocado fruits on the same car), improving avocado storage houses to allow air circulation and

4. Shumeta Z. Avocado production and marketing in Southwestern Ethiopia. Trend Agricul Econo 2010;3:190-206.

5. Garedew W, Tsegaye B. Trends of Avocado (Persea americana M) Production and its Constraints in Mana Woreda, Jimma Zone: A Potential Crop for Coffee Diversification. Trend Horticul rese 2011;1:20-26.

6. Gaillard J, Godefroy J. Avocado: The Tropical Agriculturist. CTA. Macmillan, London, UK 1995.

7. Mwakalinga HA. A report on avocado value chain mapping in Siha and Njombe Districts 2014.

8. Eia. Ethiopian Investiment Agency: Investment opportunity profile for the production of fruits and vegetables in Ethiopia 2012;1-13.

9. World-Bank-Group. Ethiopia: Developing Competitive Value chains 2006;1-3.

10. Kebebew Z, Garedew W, Debela A. Understanding homegarden in household food security strategy: Case study around Jimma, southwestern Ethiopia. Res J Appl Sci 2011;6:38-43.

11. Humble S, Reneby A. Post-harvest losses in fruit supply chains 2015.

12. Droby S, Lichter A. Post-harvest Botrytis infection: etiology, development and management. Botrytis: Biology Pathol Contro, 2007.

13. Singh D, Sharma R. Postharvest diseases of fruit and vegetables and their management, Daya Publishing House: New Delhi, India, 2007.

14. Salman MM. Biological control of Rhizopus Soft Rot on Apple, Pear and Peach by Trichoderma harzianum. An-Najah National University 2005.

15. Narayanasamy P. Integrated systems for the management of postharvest diseases. Postharv Patho Manag 2006;537-554. 
16. Abdullah Q, Mahmoud A, Al-Harethi A. Isolation and identification of fungal post-harvest rot of some fruits in Yemen. PSM Microbio 2016.

17. Parveen S, Wani AH, Bhat MY, Koka JA. Biological control of postharvest fungal rots of rosaceous fruits using microbial antagonists and plant extracts-a review. Czech Mycolo 2016;68.

18. Wills R., Golding J. Postharvest: An introduction to the physiology and handling of fruit and vegetables, UNSW Press, Randwick, Australia, 2016.

19. Zorya S, Morgan N, Diaz Rios L, Hodges R., Bennett B, et al. Missing food: the case of postharvest grain losses in sub-Saharan Africa, 2011.

20. Droby S. Improving quality and safety of fresh fruits and vegetables after harvest by the use of biocontrol agents and natural materials. Int Symposi Nat Preserva Food Sys 1999;709:45-52.

21. Navi S, Bandyopadhyay R, Hall A, Bramel-Cox P. A pictorial guide for the identification of mold fungi on sorghum grain. Int Crops Res Institu Semi-Arid Trop, 1999.

22. Okoth S, Nyongesa BW, Ayugi V. Identification key for Aspergillus species isolated from maize and soil of Nandi County, Kenya 2015.

23. Chowdappa P, Chethana CS, Bharghavi R, Sandhya H, Pant RP. Morphological and molecular characterization of Colletotrichum gloeosporioides (Penz) Sac. Isolates causing anthracnose of orchids in India. J Biotechnolo Bioinforma Bioeng 2012;2:567-572.

24. Watanabe T. Pictorial atlas of soil and seed fungi: Morphologies of cultured fungi and key to species, CRC Press, USA, 2010. 